\title{
On Being Middle-Aged in a Young Subfield: An Essay
}

\section{RICHARD G. TOWNSEND*}

"Do not allow haughtiness to take you in possession," Pavlov advises the young scientist. But I'm middle-aged, not always a scientist, and if haughty can include those who draw incessantly on their own experience, I am that. I hope also that I'll be pardoned for taking in possession here the topic of my professorship in a college of education. As it happens, my subfield within educational administration - the politics of education - has all the vibrancy of a young adult; as a distinct area for specialization, it's hardly 21 years old, and those of us in it seem to be getting old together with many things that we can never have again, like the shock of altogether new analyses or methodologies.

This matter of age was brought home to me recently when I doddered into my fifties. Instead of starting my second half-century lovably and graciously, I found myself giving fiercely impossible "pop" exams, denying worth in others" community activities, pooh-poohing the research of certain others, and generally trying to devastate my targets. Those I lambasted were all considerably younger and, in one form or another, would be working effectively well after I'm gone. Before long, however, I stopped worrying about displacement by young rivals, an amiable support for the next generation returned, and I became more nostalgic than nettled about my relatively advanced stage of life.

It was then that I started realizing that if the educator's tasks of his or her twenties through forties is to become established in the profession, the gray challenge by 50 is resignation. Thus I need to give up the last remnants of wishes for omnipotence; I need to gain a realistic perspective on my "place," however large or small that might be. Psychologists say that middle-agers like myself can be at a crisis point of growth or of regression. Regression can lead to no longer worrying about improving one's students, to wresting community power as reassurance against dread of waning capacity, or to crabbing research innovation if it does not spring from the self. Growth in teaching, on the other hand, can mean doing things well that one can do well - until one might take on greater things. Growth can mean pitching in more democratically in civic services, as opposed to being manipulative. And growth in research can mean realizing that even though one's conceptual and empirical capacities are quite finite, one still can hope ultimately to produce a modest study of worth. If with middle-aged fogeyism, one is resigned to such limits, one might flower into personal, social, and professional maturity - which is akin to wisdom.

\footnotetext{
* Associate Professor, The Ontario Institute for Studies in Education.
} 
As a stand-in for other professors, let me look here just at the research arena. First I stake ideals that I had along those lines in my "prime" of life a dozen years ago. Gaps between those ideals and my performances then are mentioned, along with an explanation for my frustration. Finally, I claim that while the stuff of research greatness may be missing, academics of my ilk do have a certain valuable dependability: we can stick to long tiresome research tasks until those tasks are done. The point seems worth making at a time when there is a press to replace "unproductive" scholars with young blood.

\section{SKIRMISHING WITH IDEAS}

What true academic does not lust to generate the most significant and joyous of all university contributions - some seminal ideas for a body of related knowledge. Constructively, we'd like to turn others' theories upside down and make a real difference to kids' education. Oh, we'd feel dissatisfactions with our early efforts to perfect grand theories, but we'd persevere in uncovering, inferring, dissecting, reshuffling, and synthesizing. From all this, some useful truths would be pried loose about how things in education happen and how people around schools behave. The truth would be ones that we could be proud of, that would lead to interactions with practicing teachers and colleagues having the same intellectual interests, and that would evoke that sublime (if vain) academic salute, adoption in classrooms and citation (preferably friendly). In the U.S., where some professors have WATS lines which enable them to telephone offices long-distance at no expense, I might become a subject of their gossip, e.g., "Did you hear that he has a helpful article coming out in such-and-such a journal?" Or "Did you hear how his research led to certain gains for education?" When I'd stroll the halls at national conventions of the American Education Research Association or at teachers' conferences, people that I respect would hail me with salutes for articles I'd written. A decade or more ago, I even thought I might be lucky enough to beat others out - my North American milieu is quite competitive - with my work becoming a focal point for educational thought!

Things haven't worked out that way. By way of explanation, I could sigh and give the habitual academic grievance, "Even with most summers off, I've had no time to do full justice to various research projects." That explanation implies that, quite rudderless amidst the jostling demands of the university, I don't know how to slot hours effectively. That could be. To salvage larger increments of my academic life for scholarly pursuits, probably I should "delegate" more, e.g., I could ask graduate students to write the first drafts of letters of recommendation I prepare for them (an ex-colleague does that). I could expect research assistants to work three times their paid hours on a project (another ex-colleague does that with hungry students). And since scholarship and teaching enrich each other, I should learn how to better handle two arenas at once, e.g., one-third of what I teach could reflect $m y$ immediate research interests. Or, when I fly 300 miles north to teach an off-campus course, I might stay an extra day to undertake local research with some interested teachers there; or, when I finish briefing some 
school business officials, I should re-use that material in my class of teachers and principals. (But, hold on, what do these educators care about business concerns?) Further, in my list of "salvations," I could shuck low priorities (like going to meetings and to university students' end-of-term parties) and say "No" more resolutely to workshop-organizers - since emphases on those activities can lead to underestimatings of initiatives in researchable ideas. But such a streamlined time-management "fix" seems to put the onus of reform almost entirely on me, overlooking the possibility that the university might do more to keep the decks clear for the professor whose most sensitive professional concern, sense of selfworth, and employability is wrapped-up in chasing ideas that "work" for schools.

The trouble is, of course, that ideas show up pressing, unexpected, and unsortedout; distinctions need to be made between the fundamental and trendy, the insightful and clever, the creative and the merely exhuberant. Ideas turn up too just as I've got to instruct, consult, or - as a department member - help stave off organizational chaos. The shame of this thrust away from core research is, as Francis Bacon warned 400 years ago, that it only yields the second prizes in the academy:

Whereas the more constant and devout kind of professors of any science ought to propound to themselves to make some addition to their science, they convert their labors to aspire to certain second prizes. . . and so that patrimony of knowledge cometh to be sometimes improved, but seldom augmented.

Harold Silver has put it another way: quality in idea-effectiveness is not wellserved by academics like myself having to balance a host of competing pressures. Agreed, the preceding may sound like excuses of a part-time student. But typically, as a researcher having to carve out a special zone of important inquiry that's sufficiently unique to call one's own, this professor is a part-timer too. If James Coleman had to juggle all the communications expected of this professor, would even he be able to achieve break throughs? Regularly?

\section{IN COLEMAN'S FOOTSTEPS?}

I mention Coleman because he was one of my early heroes in political research enriching our understandings of educational processes. Long before he succeeded in sparking years-long debates in the U.S. with vast numerical analyses of equal opportunity and private schools, Coleman read an article in Saturday Review on a school crisis in Denver; he placed that together with disparate experiences in other civic controversies in Scarsdale, Cincinnati, Mason City, Pasadena, and elsewhere. He integrated ideas too from Coser's Foundation of Social Conflict, Key's Southern Politics, and Warner's Democracy in Jonesville. In due course, he explained the development of stresses within a single community, positing ways in which those forces might be interrupted and diverted (possibly by school people wanting to get on. with the job of connecting with students instead of having to fight political battles): Coleman even propounded a Gresham's Law of 
Conflict, "where harmful and dangerous elements drive out those which keep a community's conflicts within bounds." For one audacious but fleeting moment some 25 years later, I hoped to do as well theorizing on a pragmatic topic that many educators have identified: what to do when enrollments decline and parents start protesting over attendant school closings?

My stimulus was an article in Ontario's Mississauga Times, reporting tensions between two neighborhoods over which one of their elementary schools would have to close. That story reminded me of similar bitterness between neighborhoods within Windsor, Etobicoke, Halton, Verdun, and Clarkson. Was there some pattern in these contests? Are there causes and is there a structure for this acrimony that can be laid bare - incisively and usefully?

Squeezing data from my case pretty hard, I quickly start to map a process having five distinct phases. That process opens with "Parents Try to Find Reasons to Continue Their Kids' School When Enrollments Decline." Here, parents emphasize impressionistic data about enrollment gains, e.g., "We keep seeing pregnant women and tricycles on our streets." My fifth phase is, "Defeated Parents Broaden the Scope of the Conflict." In this final stage, once a board finally decides to shut one school in favour of another one that is nearby and also declining, the losers threaten to "punish" the winning neighborhood, e.g., they say they won't patronize shops there! To symbolize the quality of several pages of such notes, including the questions I posed for myself about each phase, I need only reproduce my shortest entry:

\section{Phase 3 - Parents Make Major Pitch}

En masse, parents turn up at Board meetings with placards, arguments, and rebuttals of any financial information injurious to their school's continuance. (Do they need an editor to make their statements more direct, less rhetorical?) A neighborhood association may ask for a change in the established speaking order. (Why? With what effect?) Very recent and vague statements by officials may be misquoted to substantiate a continuance of the schools in jeopardy. Pleas may be made to keep the buildings open for at least one more year, so the Board can confirm its enrollment projections while neighborhoods have time to adjust. Tensions may be high as a Board member says that the community as a whole is fractured and that no decision can satisfy everyone. Board members may ask, "How can I vote for this school to continue when I voted against continuing a school in my own neighborhood?" (Is this meeting only a ritual to educate the parents, with conclusions already reached?) Parents may criticize board members. (Is this a mistake? Is attack better directed at administrators?)

This was the initial texture of my "shot" at becoming as widely quoted on conflict as James Coleman. So far, reward seemed to be more in the dense data themselves than in any marvellous conclusions. But then in my experience, conclusions always are elusive. 


\section{FINDING SOME PROBLEMS}

Some time later, when I glance again at my five-phase process of inter-neighborhood conflict, remorse and horror strike. My process is indigestible, too crudely mired in particulars; the level of discourse needs to be "jacked up" to more of a conceptual level dealing with a range of community issues (not just school closings). Although details are different and the focus on tensions between communities also varies, my phases are faintly reminiscent of ten stages of small-town decline mapped earlier by Burlingame; a different way of arraying my data seems required. As well, I'll have to appraise the post-Coleman literature on conflict along with volumes by still other scholars on partisanship, emergence of leaders, communication through confrontation, and policy formation. Damn! My $n$ of cases is too small - I ought to visit sites of a dozen more such conflicts. Worse yet, my notes don't critically expose existing assumptions or nefarious interests; therefore my phase model is useless to those who would develop alternate paths to governance. Worry hovers above me that my schema also underplay the contributions to this conflict by trustees and administrators; profound hypotheses need to be framed, perhaps connecting government styles to community conditions. And since theory is still the area of great payoff in the career of a researcher, I'll have to produce a cohesive and memorable metaphor or something like Gresham's Laws for Driving Out Productive Protest.

Other causes for recoil exist. My focus on conflicting neighborhoods is interesting but, for significance's sake, the unity of analysis ought to deal with squabbles between provinces, nations, blocs of nations and - to please my younger kids who like "Star Wars" - galaxies! (As this theory project would consume months of my "family time," surely I'd feel better if my children could directly enjoy the fruits of my labor.) Not the least offensive sin among my notes, once I detach myself from them, is a certain tone; parents almost come across as not being capable by themselves of understanding what they are doing and what others are doing to them. That haughtiness would have to go. Finally, although I am working in a vein that scores of other researchers are mining, I need to ask myself the "crunch" question - does my research about governance really make a hoot of difference to those on the front lines of schools who want aid in improving the delivery of their services?

Thus my tasks are cut out for me. In short, after resolving the "so-what?" question, I'll have to dig more deeply for field data, make more note cards from scholarly sources, and concentrate more resources at theorizing. I realize now, fully, that what I ultimately produce along these lines will not surpass Coleman's work on community conflict, but I no longer have that youthful urge to outdo giants. Yet like others of my age who are not withdrawn or embittered, I will persevere. In one guise or other, I'll stick with this project until it yields something helpful. For in spite of all my complaints about time and other rationalizations for failure, I'm unwilling to give up my research ideals. I wager that's the 
stance of other "unproductive" scholars in education too.

I have used my experiences here as a convenient symbol of middle-aged researchers who, drawing on "contributory" discipline, keep on working even though they're not academic "stars." I've used the topic of decline and protest as a symbol too for an education professor who, in living past his original ideals, has experienced a certain personal decline about which he inwardly protested. As a result, he is now resigned to error, even in himself. He's also resigned to trying to be merely competent, and not great. Yet that resignation is tempered with a certain hope, perhaps shared by others in similar straits: if we keep cultivating our research gardens, something useful - however modest - may yet grow. Age, it seems, does not extinguish hope.

\section{NOTE}

1. Of all the average academics in the world there are few that I envy more than the averagc faculty members at the University of California. They devote an average of 23.1 hours per week to research and creative activity! This does not include such possibly creative pursits as course preparation (11.6 hours), regularly scheduled course instruction ( 5.6 hours), supervising independent/special study ( 2.6 hours), participating in oral exams ( 0.3 hours), student advising (3.4 hours), other instructional activities such as grading papers or supervising diessertations ( 4.4 hours), university service ( 6.2 hours), and professional activities/public service (4.9 hours). (Source: press release by University of California Statewide Administration, November 9, 1981, based on a Faculty Time Use Survey prepared by a private research organization not connected to the University.)

\section{REFERENCES}

Burlingame, M. "Declining Enrollments and Small Rural Cities and Districts: An Exploratory Analysis," Education and Urban Society, 11, 3, pp. 313-332.

Coleman, J.S. Community Conflict, The Free Press, 1957.

Silver, H. "Need for Loncliness of the Long-Distance Thinker." The Times Higher Education Supplement, January $30,1978$. 